\title{
Mediasi: Problem Solving Technique Dalam Tiga Wajah Hukum Indonesia
}

$\begin{array}{ll}\text { Judul Buku } & \text { : Mediasi Dalam Perspektif Hukum Syari'ah, Hukum Adat, Dan HukumNasional } \\ \text { Penulis } & \text { : Prof. Dr. Syahrizal Abbas } \\ \text { Penerbit } & : \text { Kencana } \\ \text { Tebal } & : \text { XVII + 415 halaman } \\ \text { Terbit } & : \text { Mei-2009 } \\ \text { Peresensi } & : \text { Abdul Malik }\end{array}$

Sebagai zoon politicon, manusia tidak akan pernah mungkin bisa terhindar dari adanya konflik, kendatipun dalam proses interaksi dan sosialisasi, mereka cenderung menghindari timbulnya konflik sebagai upaya preventif. Sebuah pengibaratan sederhana, dinamika kehidupan manusia dan konflik merupakan dua sisi mata uang logam yang tidak dapat dipisahkan dan selalu bersinggungan. Untuk itulah, konflik akan terus berkembang selama bola salju kehidupan masyarakat terus menggelinding makin membesar, dan tidak ada sebuah hal dari konflik apapun kecuali ada solusinya.

Mediasi merupakan salah satu bentuk alternatif penyelesaian sengketa/konflik (Problem Solving Technique) yang dilakukan baik di pengadilan maupun di luar pengadilan. Mediasi tumbuh dan berkembang sejalan dengan keinginan manusia yang ingin menyelesaikan sengketa/konflik secara cepat, tepat dan memuaskan kedua belah pihak tanpa ada pihak yang menjadi pemenang dan pihak yang kalah, melainkan sama-sama menang (win-win solution)

Sejauh ini mediasi telah terbukti mampu menyelesaikan sebagian besar konflik persengketaan di tengah-tengah masyarakat sesuai dengan apa yang diinginkan fitrah manusia. Mediasi merupakan sebuah jawaban atas keinginan masyarakat yang mencari jalan penyelesaian sengketanya sehingga bisa hidup damai, aman, adil dan sejahtera. Mediasi juga menjadi jalan yang efektif dalam memberikan kesadaran kepada kedua belah pihak yang bersengketa untuk bermusyawarah, mencari dan menemukan jalan yang terbaik dalam menyelesaikan sengketa mereka. Oleh karena itu, mediator menjadi inti dalam mencari pola dan strategi yang kemudian ditawarkan kepada kedua belah pihak.
Dalam mediasi, skill merupakan unsur yang sangat urgen bagi seorang mediator dalam menentukan berhasil tidaknya proses mediasi yang sedang di tanganinya. Bagi mediator, mediasi adalah keahlian yang harus diasah, dirasakan, dan harus dimaknai dalam menjembatani para pihak yang bersengketa.

Buku Mediasi Dalam Persfektif Hukum Syari'ah, Hukum Adat, Dan Hukum Nasional karya Prof. Dr. Syahrizal Abbaz adalah sebuah karya yang mengkaji dan membahas tentang mediasi, bukan saja tentang pengertian atau sejarah mediasi, tetapi juga menyajikan cara-cara menjadi mediator yang handal lengkap dengan syarat-syarat dan skill yang harus dimiliki mediator.

Syahrizal Abbaz dalam karyanya ini, menyajikan berbagai informasi penting tentang mediasi. Mediasi sebenarnya telah mendapat tempat dari sejumlah sistem hukum yang ada di Indonesia, yaitu hukum Syari'ah, hukum Adat dan hukum Nasional. Ketiga sistem hukum inilah yang menjadi inti bahasan Syahrizal Abbaz dalam bukunya tersebut. (BAB III-V).

Pada bab awal Syahrizal Abbaz mencoba menerangkan mediasi, ruang lingkup, manfaat mediasi serta prinsip-prinsipnya. Mediasi sebagai alternatif untuk menyelesaikan sengketa bertujuan mewujudkan kesepakatan damai dengan melibatkan pihak ketiga yang netral dan imparsial. Demi mewujudkan kesepakan damai tersebut maka mediator harus memahami dan mengaplikasikan prinsip-prinsip dari mediasi sebagai landasan filosofi. Adapun prinsip dasar (basic principles) dari mediasi adalah prinsip kerahasiaan (confidentiality), prinsip sukarela (volunteer), prinsip pemberdayaan (empowerment), prinsip netralis (neutrality), dan prinsip solusi yang unik (a unique solution). (Hal 28) 
Unsur penting lainnya dalam mewujudkan suatu perdamaian adalah kemampuan mediator sebagai persyaratan berupa kemampuan personal dan formal. Kemampuan personal antara lain kemampuan membangun kepercayaan para pihak, kemampuan menunjukkan sikap empati, tidak menghakimi dan memberikan reaksi positif terhadap sejumlah pernyataan yang disampaikan para pihak dalam proses mediasi, walaupun ia tidak setuju dengan pernyataan tersebut. Selain itu mediator juga harus memiliki kemampuan komunikasi yang baik, jelas, teratur serta mudah dipahami para pihak karena menggunakan bahasa yang sederhana. (Hal 60-63)

Lebih lanjut, dalam pembahasan berikutnya penulis buku ini menyajikan konstruksi mediasi perspektif Syari'ah yang merupakan manifestasi dari Islam rahmatan lil alamin, praktik mediasi juga tertuang dalam al-Qur'an surat al -Hujarat ayat 9 yang artinya: "Dan jika ada dua golongan dari orang-orang mukmin berperang, maka damaikanlah antara keduanya...". Ayat tersebut menjadi landasan bahwa al-Qur'an melegitimasi upaya damai sebagai jalan terbaik dalam menyelesaikan sengketa. Rasulullah adalah mediator handal terbukti banyak sengketa yang berhasil didamaikan oleh beliau, diantaranya: saat mendamaikan masyarakat Makkah pada peletakan kembali Hajar Aswad, dan perjanjian Hudaibah ketika kaum muslimin ingin menunaikan ibadah umrah.

Selain dalam hukum Syari'ah, dalam hukum Adat pun konsep mediasi telah lama menjadi sebuah solusi alternatif untuk menyelesaikan sengketa. Hukum Adat memiliki karakter yang khas dan unik bila dibandingkan dengan sistem hukum lain. Hukum Adat lahir dan tumbuh dari masyarakat, sehingga keberadaannya bersenyawa dan tidak dapat dipisahkan dari masyarakat. Hukum Adat tersusun dan terbangun atas nilai, kaidah, dan norma yang disepakati dan diyakini keberadaannya oleh komunitas masyarakat Adat. Hukum Adat memilki relevansi kuat dengan karakter, nilai, dan dinamika yang berkembang dalam masyarakat Adat. Dengan demikian, hukum Adat Indonesia merupakan penjelmaan dari kebudayaan masyarakat Indonesia. Hukum Adat bersandar pada alam pikiran bangsa Indonesia yang tidak sama dengan alam pikiran yang menguasai sistem hukum Barat atau sistem hukum lainya. (Hal 235) Dalam menyelesaikan sengketa, hukum Adat menggunakaan empat mekanisme musyawarah dengan bentuk mediasi, negosiasi, fasilitasi, dan arbitrase.(Hal 249) Para tokoh Adatlah yang kemudian berperan sebagai mediator dalam menyelesaikan sengketa, baik itu ranah privat maupun ranah publik.

Di akhir bukunya Syarizal Abbaz memberikan informasi terkait dengan mediasi perspektif hukum Nasional. Sejarah berbicara bahwa mediasi telah dikenal masyarakat Indonesia sejak zaman kolonial Belanda, akan tetapi hanya terbatas pada kasus-kasus keluarga dan perdata pada umumnya seperti perjanjian jual beli, sewa-menyewa, dan berbagai kasus perdata lainnya. Pada perkembangannya mediasi secara konkret baru digunakan sebagai salah satu bentuk penyelesaian sengketa, baik di pengadilan (litigasi) maupun di luar pengadilan (non litigasi) setelah lahimya UU No.30 Tahun 1999 tentang Arbitrase dan Alternatif Penyelesain Sengketa, Peraturan Pemerintah (PP) No. 54 Tahun 2000 tentang Lembaga Penyediaan Jasa Pelayanan Penyelesaian Sengketa Lingkungan Hidup di Luar Pengadilan, dan Peraturan Mahkamah Agung (PERMA) No. 02 Tahun 2003 tentang Prosedur Mediasi di Pengadilan kemudian disempurnakan Peraturan Mahkamah Agung (PERMA) No. 1 Tahun 2008.

Buku Mediasi Dalam Persfektif Hukum Syari'ah, Hukum Adat, Dan Hukum Nasional karya Prof. Dr. Syahrizal Abbaz ini disajikan secara lengkap terkait dengan mediasi serta teknik-teknik handal menjadi mediator. Akan tetapi ada satu hal yang terlupakan oleh Syahrizal Abbaz dalam bukunya ini, yakni tentang teknik-teknik mediasi. Sebenarnya tentang teknik mediasi telah disinggung oleh penulis, akan tetapi secara general dan belum terperinci.

Terlepas dari kekurangannya, buku ini sebagaimana disampaikan Syahrizal Abbaz pada kata pengantar adalah hasil riset post doctoral dalam bidang pembandingan hukum dan mediasi (comparative law and mediation) di McGill University Montreal Canada tahun 2008. Buku ini juga 
mendapat pengayaan materi training mediasi di St. Stephen's house community di Toronto Canada. Oleh karena itu secara akademik buku ini memiliki argumentasi ilmiah yang tidak diragukan lagi. Dengan argumen ilmiah serta dikemas dengan bahasa yang ringan dan mudah dipahami sehingga buku ini sangat layak dikonsumsi atau menjadi referensi mahasiswa hukum (syari'ah), dosen, praktisi hukum, dan mediator khususnya. 